High carbon losses from established growing sites delay the carbon sequestration benefits of street tree plantings - A case study in Helsinki, Finland

\title{
Riikonen, Anu
}

2017-08

Riikonen , A , Pumpanen , J , Mäki , M J \& Nikinmaa, E 2017 , ' High carbon losses from established growing sites delay the carbon sequestration benefits of street tree plantings - A case study in Helsinki, Finland ' , Urban Forestry \& Urban Greening , vol. 26 , pp. 85-94 . https://doi.org/10.1016/j.ufu

http://hdl.handle.net/10138/300777

https://doi.org/10.1016/j.ufug.2017.04.004

cc_by_nc_nd

acceptedVersion

Downloaded from Helda, University of Helsinki institutional repository.

This is an electronic reprint of the original article.

This reprint may differ from the original in pagination and typographic detail.

Please cite the original version. 
1 High carbon losses from established growing sites delay the carbon

Anu Riikonen¹, Jukka Pumpanen, Mari Mäki \& Eero Nikinmaa

Department of Forest Sciences, University of Helsinki, Finland

${ }^{1}$ Corresponding author at: Department of Forest Sciences, P.O. Box 27, 00014

University of Helsinki, Finland. Tel.:+358503175325; E-mail address: anu.riikonen@helsinki.fi (A. Riikonen).

Keywords

13 carbon sequestration

14 tree soil carbon

15 tree biomass equations

16 urban trees

List of abbreviations

20 AB

21 ABW

22 BE

$23 \mathrm{C}$

$24 \mathrm{DBH}$

25 LOI

$26 O_{e}$

27 SOM

28 SW

$29 T_{f}$

30 WB

$31 W_{f}$

$32 \alpha$

$33 \beta$ aboveground biomass (stem, branches and leaves) aboveground woody biomass (stem and branches) biomass equation (see Appendix)

carbon

diameter at breast height

loss-on-ignition

loss-on-ignition estimated (Eq.6) for the periods between LOI samplings soil organic matter

soil water

soil temperature, as measured at tree sites

woody biomass

soil water content, $\%$ of weight, as measured at tree sites

LOI and SWC response parameter in the incubation model

temperature response parameter in the incubation model 
We assessed the net carbon (C) sequestration dynamics of street tree plantings based on 10 years of measurements at two case study sites each with different tree species in Helsinki, Finland. We assessed C loss from tree soils and tree $\mathrm{C}$ accumulation, tested the applicability of pre-existing growth and biomass equations against observations, and estimated the time point for the beginning of net $\mathrm{C}$ sequestration for the studied street tree plantings. The tree woody biomass $\mathrm{C}$ accumulation in the first 10 years after planting was $18--32 \mathrm{~kg}$ per tree. At the same time the $\mathrm{C}$ loss from the growth media was at least $170 \mathrm{~kg}$ per growth media volume $\left(25 \mathrm{~m}^{3}\right)$ per tree. If this soil $\mathrm{C}$ loss was accounted for, the net $\mathrm{C}$ sequestration would begin, at best, approximately 30 years after planting. Biomass equations developed for traditional forests predicted more stem biomass and less leaf and branch biomass than measured for the species examined, but total aboveground biomass was generally well predicted.

\section{Introduction}

48 Carbon (C) sequestration is one of the ecosystem services that encourage the planting of urban trees (McPherson et al., 2005). The $\mathrm{C}$ sequestration effects of urban tree plantings consists of $\mathrm{C}$ stock change in above- and belowground tree compartments, and soil organic matter (SOM) stock changes related to tree planting and litter production by planted trees. The belowground $\mathrm{C}$ stock of urban trees and soils is not well known, but there are indications that urban soil C stocks can be substantial (Pataki et al., 2006). In the traditional, non-urban forests of Scandinavia, the soil C stock occurs predominantly in the superficial layers and is as large as or larger than that of the vegetation (Liski et al., 2006). In urban greening, trees are planted traditionally in limited container-like soil spaces or wider structural soil (e.g. Grabosky and Bassuk 1995, Neal and Whitlow 1997, Kristoffersen 1999) volumes in which the load-bearing properties of the soil have been enhanced with stony matrices. Fine soil, suitable for tree rooting, is located in the voids of the stone matrix. In both of these methods, artificial growing media brings C-rich soil into the deep layers. Currently, Finnish municipalities use SOM contents of 10--12\% (measured as loss-on-ignition, LOI) throughout the standard 1-m-deep growth media in tree plantings (Rakennustietosäätiö, 2010). A square metre of new traditional tree growth media thus typically has a $\mathrm{C}$ stock of approximately $40--50 \mathrm{~kg} \mathrm{C} \mathrm{m}^{-2}$ and a structural soil of 10--20 $\mathrm{kg} \mathrm{C} \mathrm{m}^{-2}$; about 2--10 times more than in traditional upland forest soils in Finland (Liski et al., 2006).

In contrast to natural SOM, which has substantial proportions of slowly decomposing fractions, the artificial growth media organic matter may decompose quickly and lose $\mathrm{C}$ to the atmosphere (Bernal et al., 1998). Soil sealing (by e.g. asphalt or pavement), common in urban environments and predominantly used in combination with structural tree soils, impairs soil heat and soil water (SW) exchange (Scalenghe and Marsan, 2009) and limits the $\mathrm{C}$ input from above the ground, affecting biomass accumulation and 
by the tree exceeds the $\mathrm{C}$ loss from the growing media. The organic matter in the growing media may be derived from peat, or partially or entirely from renewable $\mathrm{C}$ sources, such as compost. In addition to its use in growing media as such, peat is a common additive used when composting sewage sludge, kitchen and food waste etc. (e.g. Himanen and Hänninen 2011), and consequently, also the SOM in compost-derived growing media tends to contain some fraction of peat. While renewable $\mathrm{C}$ originating from short-term biogenic cycle is commonly considered neutral in regards to climate change, peat-derived $\mathrm{CO}_{2}$ in energy production is currently viewed as equivalent to fossil fuel emissions (IPCC 2006). IPCC takes no stand on other uses of peat however; thus the official $\mathrm{C}$ accounting status of peat in growing media is somewhat unclear. There is a general interest in finding replacements for peat in the growing media industry however, due to both wetland protection and $\mathrm{CO}_{2}$ emissions (e.g. Defra 2009).

In a street tree planting, growing media $\mathrm{C}$ emissions can be compensated and exceeded by the $\mathrm{C}$ sequestration of trees over time. Unfortunately, the size and $\mathrm{C}$ stock of urban trees of a given age are not easily predicted (Peper et al., 2014). Currently, aboveground C stocks in urban trees are estimated with allometric tree biomass equations (BEs) developed in traditional forests, if urban-based equations are not available. Root biomass may then be estimated from a set root-shoot ratio despite its large variation between ecosystems and species (e.g. IPCC 2006). However, the accuracy of traditional forest based BEs in an urban context has been questioned (McHale et al., 2009). The particular above- and belowground environments of trees influence both the overall growth rate and biomass distribution within trees (Litton et al., 2007; Zhou et al., 2014). Consequently, the urban environment may lead to biomass distributions different from those observed in traditional forests, with consequent biomass estimation problems. In addition to biomass distribution, the tree-related $\mathrm{C}$ inputs into urban soil remain largely unknown. Root exudates and litter likely contribute to soil C stock while, especially in paved areas, the aboveground litter might not, because it is either removed or moves along, unable to enter the soil under the pavement. The purpose of this study is to estimate the long term carbon dynamics of a street tree planting in the hemiboreal city of Helsinki. We collected data from two case study street tree plantings (established according to current establishment practices in Finland) about long term $\mathrm{C}$ stock changes in the growth media and trees. These were combined with literature based tree growth equations that we tested with separate tree data from different aged street tree plantings in Helsinki, and literature based biomass equations. At the case study sites, we assessed the soil $\mathrm{C}$ stock changes occurring during the first 10 years after planting, using a LOI change-based approach. We evaluated the estimate with $\mathrm{CO}_{2}$ production of soil samples in an incubation experiment. At these sites we estimated the tree biomass accumulation from direct measurements of the case study trees. The measurements were compared against literature-based biomass equations to find the 
107 We used the data to estimate the time needed for street plantings to reach the $\mathrm{C}$ compensation point (the 108 number of years after planting required for the tree $\mathrm{C}$ capture to reach the sum of the soil $\mathrm{C}$ loss in the first 109 decade after planting) in Helsinki. Our hypothesis was that the amount of $\mathrm{C}$ lost from the growth media of 110 the case study trees would offset the $\mathrm{C}$ uptake of the tree growth during our study period, and an 111 improvement in average street tree life expectancy would be needed to obtain $\mathrm{C}$ sequestration benefits with 112 current planting practices.

\section{Materials and methods}

115 Case study sites

116 We studied the tree biomass and soil $\mathrm{C}$ changes on two separate street sites, located 800 meters apart from 117 each other, in the Viikki suburb in Helsinki, Finland, (N60 $15^{\prime}$, E $\left.25^{\circ} 03^{\prime}\right)$ over 10 years after the 118 establishment of the street. One street, $250 \mathrm{~m}$ in length, was planted with 15 common lime Tilia $\times$ vulgaris 119 Hayne trees (Tilia site) and the other (200 m in length) with 22 black alder Alnus glutinosa (L.) Gaertn. f. 120 pyramidalis Dippel 'Sakari' trees (Alnus site). The sites were established in the summer of 2002 and the 121 trees were planted in the autumn of 2002. At both sites, three different premixed structural soil mixes were 122 applied as a 1-m-deep, 3-m-wide continuous strip (Tilia site) or 15-20-m-long planting pockets for two to 123 four trees (Alnus site). Cast-iron tree gratings $2.25 \mathrm{~m}^{2}$ in size were used around the trees, and the streets 124 outside the grates were paved over with sand-jointed block pavers. The available soil volume per tree was $45--50 \mathrm{~m}^{3}$ at the Tilia site and $15--30 \mathrm{~m}^{3}$ at the Alnus site.

The structural soils consisted approximately $2 / 3$ by volume of stones ranging from 30 to $120 \mathrm{~mm}$ in size and $1 / 3$ of fine soil. In soil mix 1, the fine soil was mainly sand, clay and the SOM source was peat. In soil 2, the fine soil was derived from composted sewage sludge mixed with peat, sand and pine bark, but the contribution of peat to the final soil mix SOM could not be determined. In soil 3, the components were fine gravel, sand, clay and leaf compost (peat was not used in the composting process). For soil 1, the initial LOI was $6 \%$ and for soil $220 \%$, according to their respective manufacturers. For soil 3, the initial LOI was $4.4 \%$, based on the composition and properties of the materials used (7\% by volume of leaf compost, $20 \%$ of clay with LOI $8.3 \%$ and $3 \%$ bark mulch). Soils 1 and 2 were commercial mixes, while soil 3 was specially mixed for the study sites.

The transplanted Tilia trees were 8--11 cm in diameter-at-breast height (DBH) and Alnus 7--11 cm, respectively, and both were balled and burlapped. After transplanting, the trees were not pruned (except for dead and broken branches and shoots growing from rootstocks) until late 2008. Thereafter, the Tilia were pruned about annually to achieve the necessary crown lifting. The Alnus trees were not crown-lifted, and only branches that were damaged or leaned far out from the columnar crown shape were removed. 
144 Each soil mix on both streets was instrumented during the establishment with continuously measuring soil 145 moisture sensors (Delta T MLx2 (Delta-T Devices Ltd, Burwell, Cambridge, UK), see Riikonen et al., 2011 146 for installation details) at depths of 10 and $30 \mathrm{~cm}$ and with temperature sensors (resistor type KTY81) at 147 depths of 10,30 and $60 \mathrm{~cm}$ from the surface of the growth media.

149 Data loggers (DP-158; Envic Oy, Turku, Finland) read the temperature and SW sensors from July 2003 onwards at 1-30-min intervals. At the Alnus site, soil moisture sensors at $30 \mathrm{~cm}$ depth were installed in 2005 and data from $10 \mathrm{~cm}$ depth was used before that. Soil moisture and soil temperature $\left(T_{f}\right)$ were averaged to $30-$ min means, and missing data, due mainly to periods of datalogger malfunctions, were gap-filled with linear interpolation. The SW content could only be reliably measured while the $T_{f}$ was $>0{ }^{\circ} \mathrm{C}$; periods when ground was frozen were filtered out and gap-filled linearly (Kornelsen et al. 2012) (most missing SW values in 2003: $52 \%$, least missing values in 2006; $7 \%$ ). The measured volumetric water content was transformed to percentage of soil weight $\left(W_{f}\right)$.

\section{Soil sampling and analysis}

159 Soil samples were collected in the autumn 2005, 2008 and 2011 from two pits in each soil mix and site

160 (2x3x2 sampling pits each year, each located in separate planting pocket at the Alnus site, and at least $10 \mathrm{~m}$ 161 apart at the Tilia site). The average distance from the nearest tree was 2--3 m, depending on parked cars and 162 other practical considerations. The pavement was removed and a pit with a diameter of $30--50 \mathrm{~cm}$ was dug 163 with hand trowels. In 2005, the pits were dug down to depths of $30 \mathrm{~cm}$ (sampling depth 0--30 cm, altogether 16412 samples), in 2008 to at least $60 \mathrm{~cm}$ and to $90 \mathrm{~cm}$ where possible (sampling depths $0--30 \mathrm{~cm}(\mathrm{n}=12), 30--$ $16560 \mathrm{~cm}(\mathrm{n}=12)$ and 60--90 cm (n=11), altogether 35 samples), and in 2011 to $60 \mathrm{~cm}$ (sampling depths 0--30 $166 \mathrm{~cm}(\mathrm{n}=12)$ and $30--60 \mathrm{~cm}(\mathrm{n}=12)$, altogether 24 samples $)$. The rocks $(\geq 30 \mathrm{~mm})$ in the soil mix were separated from the fine soil. All the fine soil excavated from each sampling pit was weighed, thoroughly mixed and a sample of approximately 3 liters was taken from each depth. The sampling pit volume up to each depth was estimated by measuring the volume of vermiculite required to fill the pit. After each measurement the pit was vacuumed empty of any vermiculite and filled back with the original soil material once all measurements were completed.

The soil samples were divided in parts for further analysis. One subsample of approximately $400 \mathrm{~g}$ was dried at $105^{\circ} \mathrm{C}$ and measured for loose dry bulk density, LOI $\left(550{ }^{\circ} \mathrm{C}, 2 \mathrm{~h}\right)$ and particle-size distribution (dry sieving and laser diffractometer Coulter LS230; Beckman Coulter Inc., Krefeld, Germany). Another separate subsample was reserved for incubation to estimate the soil $\mathrm{CO}_{2}$ production rate. The subsamples for incubation were stored at $10{ }^{\circ} \mathrm{C}$ for $0--30 \mathrm{~h}$ before initiation of the incubation experiment. 
In 2005 and 2011, from all 12 and 24 soil samples collected, respectively, subsamples were incubated and

181 measured for $\mathrm{CO}_{2}$ production. In 2008, subsamples were collected and incubated from all sites at depths of $182 \quad 0-30 \mathrm{~cm}$ and a random sample of one-half of the sites at 30-60 and 60-90 cm. All visible roots were picked 183 out from the soil samples, and eight 20 -ml portions from each sample were placed in 120-ml incubation 184 bottles and weighed. The bottles were then flushed with compressed air at atmospheric $\mathrm{CO}_{2}$ concentration and sealed. The bottles were immediately placed randomly at 5, 10,15 and $25^{\circ} \mathrm{C}$, two bottles at each temperature. For each soil sample, two bottles were filled with air only and their $\mathrm{CO}_{2}$ concentration was used as a background level in calculating the results.

After $24 \mathrm{~h}$, the bottles were placed in an ice bucket and gas samples were taken and analysed immediately for $\mathrm{CO}_{2}$ content with gas chromatography. $\mathrm{CO}_{2}$ production during the incubation time $\left(R, \mathrm{CO}_{2} \mathrm{l}^{-1} \mathrm{~h}^{-1}\right)$ was calculated for each subsample, based on the $\mathrm{CO}_{2}$ concentration in the incubation bottles and measured by gas chromatography (Hewlett-Packard Co., Palo Alto, CA, USA; Jaakkola and Simojoki, 1998), as:

where $\mathrm{CO}_{2}$ inc $\left(\mathrm{CO}_{2} \mathrm{l}^{-1}\right)$ is the $\mathrm{CO}_{2}$ content of the incubation bottle after incubation, $\mathrm{CO}_{2 \text { ref }}\left(\mathrm{CO}_{2} \mathrm{l}^{-1}\right)$ is the $\mathrm{CO}_{2}$ content of the air used in filling the bottles prior to incubation and $\mathrm{h}$ is the incubation time in hours. Then the $\mathrm{C}$ loss $\left(\mathrm{g} \mathrm{CO}_{2} \mathrm{~g}^{-1} \mathrm{~h}^{-1}\right)$ was calculated as:

where $R$ is the $\mathrm{CO}_{2}$ produced in the incubation bottle per hour of incubation $\left(\mathrm{CO}_{2} \mathrm{l}^{-1}\right), V_{b}$ is the volume of 199 the incubation bottle (1), $M_{s}$ is the weight of the incubated sample (g), $V_{m}$ is the gas constant $\left(1 \mathrm{~mol}^{-1}\right), M_{C O 2}$ 200 is the molar mass of $\mathrm{CO}_{2}$. $\mathrm{C}$ loss in the incubation experiment $\left(\mathrm{g} \mathrm{g}_{\mathrm{SDw}} \mathrm{h}^{-1}\right)(P)$ was calculated from the $\mathrm{CO}_{2}$ 201 production:

where $M_{C}$ is the molar mass of $\mathrm{C}\left(\mathrm{g} \mathrm{mol}^{-1}\right)$.

\section{Calculation of soil C storage change}

205 The change in soil $\mathrm{C}$ stock was calculated as LOI change between the sampling times and from the initial value for different soils and sites (2002--2011). The proportion of C in the LOI used in the calculation was 0.56 (Hoogsteen et al., 2015). Estimates of soil C stock changes were calculated per standard $25 \mathrm{~m}^{3}$ of soil per tree (Rakennustietosäätiö, 2010) instead of the actual soil volume allocated for each tree at the study sites, to allow easier comparison between sites, soil mixes and tree species. This estimate was compared 
with one based on the incubation experiment. Since the first soil sampling for incubation was performed in

2112005 , the comparison covered the years between 2005 and 2011.

213 The incubation-based estimate was obtained in two steps. First, we developed an Arrhenius-type model to

214 predict $\mathrm{C}$ loss as a function of the measured $T_{f}$, SW and LOI content and parameterized it with the soil

215 incubation data (Eq. 4). The three estimated parameters were used in the model (Eq. 5); the intercept $(\lambda)$,

216 combined LOI and SW response parameter $\alpha$ and parameter $\beta$ describing the temperature response. After the

217 testing of year-, soil- and site- specific datasets, the least number of separate models that presented no

218 heteroscedasticity problems were chosen. As a result, the model was fitted separately for each soil type and

219 site $(\mathrm{n}=40$ in each combination):

$\ln (P)=\lambda+(\propto \ln (O) \ln (W))+\beta T$,

where $O$ is the LOI of the soil sample (\% of dry weight), W (\% of dry weight) is the $S W$ of the soil sample and $\lambda, \alpha$ and $\beta$ were the fitted parameters. The model was then applied to predict the soil $\mathrm{C}$ loss, based on the measured $T_{f}$ and water content at the studied sites:

C loss $=\exp \left(\lambda+\left(\propto\left(\ln O_{e}\right) \ln W_{f}\right)+\beta T_{f}+(R M S E / 2)^{2}\right)$

where $\lambda, \alpha$ and $\beta$ are the parameters fitted in the preceding step, $W_{f}$ is the measured $S W$ content (\% weight) and $T_{f}$ is soil temperature $\left({ }^{\circ} \mathrm{C}\right)$ hourly averages. The correction for unbiasedness (Baskerville, 1972) was calculated from the root-mean-squared error (RMSE) of the parameter estimation. The initial LOI $\left(O_{e \text { ini }}\right)$ at the starting point of the model was generated with a combined two first-order kinetic model (Bernal et al., 1998), based on the initial LOI and measurements from the soil samples taken in 2005, 2008 and 2011 as: fitted parameters. After the first time step of the incubation model, subsequent $O_{e}$ values were obtained dynamically from the periodic $\mathrm{CO}_{2}$ production estimates calculated with the model. Half-hourly measurements of $T_{f}$ at depths of $10 \mathrm{~cm}$ were used for depths of $0--20 \mathrm{~cm}$, at $30 \mathrm{~cm}$ for depths of $20--45 \mathrm{~cm}$ and at $60 \mathrm{~cm}$ for depths of $45--100 \mathrm{~cm}$. The SW measured at $10 \mathrm{~cm}$ was used for the $0-20-\mathrm{cm}$ layer and measurement from $30 \mathrm{~cm}$ for lower levels.

239 The incubation model based total $\mathrm{C}$ loss for each $25 \mathrm{~m}^{3}$ of tree soil was calculated as: 
241 where $\sigma$ is the loose soil bulk density $\left(\mathrm{kg} \mathrm{m}^{-3}\right)$ and $v$ is the proportion of fine soil in the structural soil $\left(\mathrm{m}^{3} \mathrm{~m}^{-}\right.$ $\left.2422^{3}\right)$.

243 The LOI based C loss ( $\mathrm{kg}$ per $25 \mathrm{~m}^{3}$ of tree soil) was separately calculated, based on the LOI change between 244 the soil construction and year 2011:

245 Total $C_{\text {LOI }}$ loss $=\left(\left(L_{2002} c \sigma v\right)-\left(L_{2011} c \sigma v\right)\right) 25$ Eq. 8

246 where $L_{2011}$ is the measured loss on ignition $\left(\mathrm{g} \mathrm{g}^{-1}\right)$ measured in 2011, $c$ is estimated proportion of $\mathrm{C}$ in the 247 LOI (0.56; Hoogsteen et al., 2015), $\sigma$ is loose soil bulk density $\left(\mathrm{kg} \mathrm{m}^{-3}\right)$ and $\mathrm{v}$ is proportion of fine soil in the 248 structural soil $\left(\mathrm{m}^{3} \mathrm{~m}^{-3}\right)$.

\section{Tree biomass measurements}

250 The development of tree aboveground woody biomass (ABW) at the study sites was calculated from 251 measurements made of same 6--12 trees per species in August 2005, 2008 and 2011, and leaf biomass from 252 measurements taken in all years from 2004 to 2011. The selection of observed trees (a combination of 253 systematic and random sampling, each soil type at site was equally represented) and leaf area measurements are described in Riikonen et al. (2011). Tree trunk diameter was measured at soil surface, at height of 130 $\mathrm{cm}$ and above all first-degree branches. The height and diameter of each first-degree branch were recorded. The living crown was divided horizontally into three equally long sections, and leaf samples were taken from the median diameter branch of each crown section for leaf area and dry weight measurements. A relationship

258 was fitted between the branch basal area and leaf area and used to predict the leaf biomass for all branches 259 within the tree crown (Riikonen et al. 2011).

261 The branch woody biomass (WB) for Tilia was based on 206 and for Alnus 46 branches, bulked per species, pruned from the study site trees. A power function was fitted to estimate the branch dry biomass, based on its diameter:

Here, $M_{w b}$ is the woody biomass of the branch $(\mathrm{kg}), D_{b}$ is branch diameter $(\mathrm{mm})$, and $\delta$ and $\mu$ were the estimated parameters. The biomass of all branches in each tree was calculated based on the branch diameters measured. The tree trunk volume was calculated from the trunk diameter measurements as stacked cylinders and converted to biomass with specific gravity for Tilia americana L. (0.40) and Alnus rubra Bong. (0.43) 270 (Alden, 1995).

271 Living tree roots encountered in the sampling pits during soil sampling in 2008 and 2011 were collected for root biomass estimation, washed and weighed $\left(R_{f}\right)$. Additionally, small roots that could not be separated in 
the field were separated from the dried soil sample, weighed and calculated per $\mathrm{kg}$ of soil $\left(R_{d}\right)$. The total dry root biomass for each sampling pit was calculated, based on the roots collected in the soil sampling as:

where $j$ is the root dry-to-fresh weight ratio, $M_{p}$ is total mass of the collected fine soil sample from the sampling pit $(\mathrm{kg})$ and $V_{p}$ is volume of the pit $\left(\mathrm{m}^{3}\right)$.

The total tree root dry biomass $\left(\mathrm{g} \mathrm{m}^{-3}\right)$ was estimated from roots in the collected soil samples, assuming the root density was equal to the average of all sampling pits at each site. This value was assumed to represent root density for the entire root system. It is estimated that the root system covers an area with a radius of $38 \mathrm{x}$ the DBH of the tree in question (Day et al., 2010), which exceeded the tree soil dimensions already in 2008; thus it was assumed that roots had grown throughout the entire soil volume. We assumed that the root density in the root ball at planting time was equal to the value in 2011 and calculated an estimate of root biomass at planting, based on the root ball volume (diameter $100 \mathrm{~cm}$ ).

\section{C stocks in branch prunings and leaf litter}

The contribution of exported biomass fractions (tree litter $\mathrm{C}$ and pruned branches) to tree $\mathrm{C}$ sequestration was estimated with an exponential decay function (Olson, 1963), to account for these non-living compartments of tree sequestrated $\mathrm{C}$ at a given time. The function was applied for each fallen leaf and pruned branch cohort separately for each year:

where $M_{r}$ is the remaining leaf or branch biomass, $M_{0}$ is leaf or branch biomass (kg) at $t_{0}$ (years), $k$ is decay factor (Tilia leaves: 0.24, Hobbie et al., 2006, Alnus leaves: 0.6, Dilly and Munch, 1996, and branches of both species: 0.22, Perruchould et al., 1999) and $t$ is years passed. We assumed that the $\mathrm{C}$ in the leaves was initially equal to the total $\mathrm{C}$ content of that year's leaf cohort and was lost at a rate equal to the total mass loss. The WB removed by pruning was measured for one half of the trees, selected randomly, at each

\section{Prediction of tree $D B H$, biomass and $C$}

300 To estimate the compensation point (the number of years after planting required for the tree $\mathrm{C}$ capture to 301 reach the sum of the soil $\mathrm{C}$ loss in the first decade after planting, not accounting for possible soil $\mathrm{C}$ changes after first 10 years) for the case study trees, we needed to predict the long-term tree growth and biomass accumulation. For this we needed models that predict both the tree growth over time and how the biomass is distributed among the various tree parts. We compared existing DBH growth models (we found two for Tilia, but only one for Alnus) (Table 2) with observations from sample trees that we collected for this 
purpose. The biomass and C stock predictions were based on BEs (Table 2, Appendix), assessed and selected by comparing the $\mathrm{BE}$ predictions with the measured values explained above.

We collected the DBH values from 19 Tilia sp. street tree plantings in Helsinki with known planting year and at least six trees still remaining of the originally planted. We used either the latest DBH data from the

311 City of Helsinki street tree database or measured at least six randomly chosen trees per planting in 2012-

312 2014. Only two known Alnus glutinosa f. pyramidalis plantings in Helsinki are older than the case study site.

313 Two datasets of earlier DBH measurements were available for one of the plantings and one set for the other,

314 and additionally, all trees were measured for DBH in 2014: altogether, the resulting dataset on Alnus DBH

315 had 5 data points (average DBH at given age). For Tilia, from 6 to 68 , on average 22 trees were measured to attain the average DBH for a planting site, and for Alnus, one planting had 22 and the other, 91 trees.

318 To predict the $\mathrm{C}$ content of the pruned branches, we applied a pruning regime the City of Helsinki aims for 319 with street trees: the trees were pruned 1, 3, 5, 7, 10, 15 and 20 years after planting and thereafter every 10 320 years. In the first 20 years, we applied a pruning of $25 \%$ and thereafter $15 \%$ of the branch biomass at each 321 pruning.

In all conversions from woody biomass to $\mathrm{C}$, we used a $45 \% \mathrm{C}$ content for both species. We used $\mathrm{C}$ content of $47.6 \%$ for Tilia (Niinemets, 1999) and 45.8\% for Alnus (Browaldh, 1997) leaves, respectively. For purposes of predicting future $\mathrm{C}$ stocks of tree planting, we assumed there was no further soil $\mathrm{C}$ stock change after the first 10 years.

Statistical analysis

The mean LOI change-based C loss for each site and soil type, and similarly, the measured and BE-predicted tree biomass compartments for individual trees in 2011, were each log-transformed and compared using 2sided Tukey's test. The incubation-based C loss prediction model parameters were estimated with SAS

333 heteroscedasticity test. The relationship between sample branch diameter and biomass in the tree biomass 334 measurements was determined with nonlinear regression (Eq. 9). DBH growth models for Tilia were compared to measurements by calculating RMSE and bias and testing the significance of the latter with ttest. The $\mathrm{p}$ value required for significant difference and/or effect was set at $\leq 0.05$ for all statistical analyses.

\section{Results}


340 The soil $\mathrm{C}$ stock at the time of establishment was approximately 400, 900 and $250 \mathrm{~kg}$ of $\mathrm{C}$ per tree in the 25

$341 \mathrm{~m}^{3}$ of tree soil in soils 1, 2 and 3, respectively. The average loss of $\mathrm{C}$ in 2002-2011 across the soils was

342 approximately $290 \mathrm{~kg}$ per $25 \mathrm{~m}^{3}$, as calculated from the LOI change (Figure 1). The highest proportional LOI 343 loss in comparison to the original LOI was measured in soil 3; only about 1/3 remained in 2011 (Figure 2).

344 The peat-based soil 1 maintained its LOI best, retaining on average, $56 \%$ of the original LOI value, with C

345 loss estimates of $100-250 \mathrm{~kg}$ per $25 \mathrm{~m}^{3}$.

346 Based on the incubation model, the average annual soil $\mathrm{C}$ loss per $\mathrm{m}^{3}$ in $2005-2011$ was $0.41 \mathrm{~kg}$, resulting

347 in a slightly lower C loss over time in all soils than in the LOI loss-based estimate (Figure 3). Model

348 parameter $\beta$ describing the temperature response was highest in soil 2, but parameter $\alpha$ combining the effects

349 of LOI and SW was highest in soil 3 (Table 3). Periods of extrapolation to $T_{f}$ values outside the incubation

350 experiment range accounted for $17.5 \%$ of the $\mathrm{C}$ loss predicted by the model. The gap-filling in the SW data

351 produced only $0.54 \%$ of the $\mathrm{C}$ loss estimate.

353 The particle-size distributions showed that in 2002, $83 \%$ of the samples by weight on average were $<2 \mathrm{~mm}$, 354 but in 2011 the corresponding value was only 58\%. Based on laser diffraction analysis, the clay content of all 355 samples was $<1 \%$.

\section{Tree biomass $C$}

358 Based on biomass measurements, an average Tilia tree showed approximately $25 \mathrm{~kg}$ of C in its WB in 2011

359 (Table 4) and sequestered approximately $18 \mathrm{~kg} \mathrm{C}$ in total WB per tree in 2003-2011. The WB of an average 360 Alnus tree had a stock of $37.5 \mathrm{~kg}$ of $\mathrm{C}$ in 2011. Including the $\mathrm{C}$ in the roots, $\mathrm{C}$ sequestration in the Alnus WB 361 in 2003-2011 showed a total of $32 \mathrm{~kg}$.

362 The branches used to predict Tilia and Alnus branch biomass, based on branch diameter, showed fairly good 363 correlation between branch diameter and biomass; the $\mathrm{R}^{2}$ values were 0.93 and 0.91 , respectively. The 364 estimated leaf and litter contribution to the total $C$ stock was high, especially for Tilia: $7.3 \mathrm{~kg}$ per tree in 3652011 (Table 4). The prunings contributed relatively little to the $\mathrm{C}$ stock in either species. Adding the $\mathrm{C}$ 366 estimated to remain in the leaf litter and pruned branches to the tree $\mathrm{C}$ sequestration estimates brought the 367 sequestered C in 2011 to $26 \mathrm{~kg}$ per Tilia tree and for Alnus to $38 \mathrm{~kg}$ per tree.

There were significant differences in all aboveground biomass compartments measured between the tree species, but only two of the seven BEs tested (Appendix) produced significantly different total or ABW estimates from the measured biomass (Table 5). However, all of the BEs showed significantly higher stem 
376 Based on the estimates of soil C loss and tree $\mathrm{C}$ sequestration, the Alnus trees sequestered 10-15\% of the mean soil C loss by 2011, while the Tilia trees achieved some $10 \%$ sequestration in comparison to the mean $\mathrm{C}$ losses from the tree soils, but the uncertainties in both soil $\mathrm{C}$ loss and tree $\mathrm{C}$ sequestration remain considerable. In the highest $\mathrm{C}$ loss soil, less than $10 \%$ of the $\mathrm{C}$ loss was sequestered by the trees, while in comparison to the lowest loss soil and site, the Alnus trees approached 40\% sequestration in 2011. These percentages include the $\mathrm{C}$ in leaf litter and prunings, as estimated for 2011. Considering only the peat-based soil 1, Alnus trees had sequestered about $30 \mathrm{~kg}$ of $\mathrm{C}$, while the $\mathrm{C}$ loss from soil 1 was estimated as $170 \mathrm{~kg}$ (average over the two sites, Figure 1).

Of the available DBH growth models for long-term biomass accumulation estimation, DBH model 2 coincided better with the measurements (Figure 6) with a relative RMSE of $20 \%$ and a bias of $0.7 \mathrm{~cm}$, while DBH model 1 showed tree sizes similar to those at the best sites measured in Helsinki with relative RMSE of $28 \%$ and a bias of $-7.4 \mathrm{~cm}$. Neither model predictions were significantly different from measurements however. The data collected from the Alnus plantings in Helsinki were too limited to assess the applicability of the prediction.

391 If Tilia growth followed prediction 2, the estimated C capture in the woody biomass of the Tilia trees would reach the mean soil $\mathrm{C}$ loss of the first decade about 55 years after transplanting (Figure 7) and the smallest soil C loss in this study (Soil 1 at the Alnus site, Figure 1) in about 30 years. The prediction for Alnus was more uncertain still, but it showed a biomass accumulation curve very similar to that in prediction 2 for Tilia, with Alnus some 5 years ahead (Figure 7). Taking the estimated litter and prunings $C$ stock into account moved the previous compensation point estimates forward by 3 years for Tilia, but in the Alnus $\mathrm{C}$ stock, the litter and prunings had little effect.

\section{Discussion}

\section{$400 \quad$ Soil C storage change}

401 High C losses from tree planting soils were seen soon after soil construction. In the two compost-containing 402 soil mixes studied, the LOI was halved in less than 10 years and most of the LOI loss took place before the 403 first soil sampling in 2005. In addition to our study, rapid SOM decline has been demonstrated for other 404 compost-derived growth media, especially when the compost was not sufficiently mature (e.g. Bernal et al., 405 1998; Sanchez-Monedero et al., 2004; Vidal-Beaudet et al., 2012). In the entirely peat-based soil mix 1, the 406 LOI loss was not as high, consistent with studies of greenhouse growth media (e.g. Prasad and O'Shea, 407 1997; Prasad and Maher, 2003). 
The incubation model gave lower values for C loss than the LOI loss measured, and the parameters for the model differed clearly between sites. Sampling structural soil is complicated by the presence of load-bearing

411 stones, and consequently the samples incubated were heavily disturbed. This may have affected the resulting $412 \mathrm{CO}_{2}$ production rates. The absence of active tree roots may also have had a suppressing effect on SOM 413 mineralization (Linden et al., 2014). The estimated parameters showed the highest temperature response in 414 the highest LOI soil mix, likely due to the higher amount of decomposable organic material. The water 415 content and LOI response were more varied, probably because the ranges of these variables did not entirely 416 overlap in the various soils and sites. Overall, the number of samples per soil and site was rather low, and the 417 site differences may be exaggerated. On the other hand, the differences between sites, such as the planted 418 tree species (e.g. Bomberg and Timonen 2009) or soil water status (e.g. Williams and Rice 2007) in long 419 term may have led to different soil microbial community and SOM decomposition on initially similar soil 420 mixes.

Based on the change in particle-size distribution and visual inspection of soil samples, an increase in coarse material was seen in the fine fraction after soil construction, originating from breakage of stones in the structural soil during handling and tamping. Assuming the change in finer fractions was similar to that seen in the coarse fraction, an addition of some $25 \%$ in volume can be roughly estimated. This would reduce the LOI loss estimates by $20 \%$. From Figure 7 we can assess that such an error has a relatively small impact on the compensation point estimates. The clay content of the samples was measured with the laser diffraction method, which gives lower values for clay content than does the pipette method (2-3 times less; Taubner $e t$ al., 2009). The clay content was low nevertheless, and no clay correction was applied in the C stock calculation.

At the time of the site establishment, the LOI of the growth media was not separately measured. The initial LOI values were bulk values from the growth media trade descriptions (soils 1 and 2) and the LOI values of the organic matter used in the soil mix for soil 3 (specially prepared $>200-\mathrm{m}^{3} \mathrm{mix}$ ). The LOI change estimates were net $\mathrm{C}$ changes in the soil, i.e. the possible contribution of root litter to the soil $\mathrm{C}$ stock was included in the net effect calculation; it would add SOM to the soil and thus reduce the soil C loss observed. The agreement seen between the LOI and incubation-based model, implies that the uncertainties were probably not major. However, the estimates of LOI half-life are especially sensitive to the types of uncertainties present in the data.

For the relatively small trees measured in this study, the differences between the various BEs for total aboveground biomass $(\mathrm{AB})$ or total $\mathrm{ABW}$ and the measured biomass were fairly small for five of the seven equations. The only model for urban Tilia trees (McHale et al., 2009) gave much higher values than the other 
445 BEs, but the authors noted that the trees were irrigated and fertilized. For Alnus, BE 5a deviated furthest

446 from the measured biomass. The source of the equation also gave separate BEs for the stem and branches

447 (BEs 5b and 5c); summing these up resulted in better estimates (Table 5).

449 While the total aboveground BEs performed fairly well, the equations for the various $\mathrm{AB}$ compartments 450 leaves, branches and trunk - did not. In Alnus, this may have been due to the different crown form (f. 451 pyramidalis) in comparison to the BEs and the lack of large branches in the biomass samples. For Tilia, 452 however, the branch biomass was more likely under- than overestimated, because large branches in the 453 biomass samples were often reduction-pruned previously. The differences between the measurements and 454 BE predictions imply that in Tilia street trees, the biomass distribution within the crown likely differs from 455 that of Tilia in traditional forests. Similar findings were recently obtained for three other species in open sites 456 (Zhou et al., 2014); stem biomass was low and branch biomass was high, but total aboveground biomass agreed somewhat with traditional forest based equations. More data needs to be gathered however, as our study only concerns a small number of trees from two species.

460 The leaf biomass of the trees measured was also consistently higher than the BEs predicted. In our data, the 461 Tilia trees annually invested approximately 40--50\% and Alnus 30--40\% of the total aboveground C increase 462 into leaves, which is on the high side but within the range for similarly aged stands in allocation studies 463 reviewed by Litton et al. (2007). The roots of the Tilia trees appeared to have relatively more C stock than 464 the roots of the Alnus trees. This may have resulted from the uncertainties in root sampling however, since the variation between samples was high. Based on the literature, belowground biomass can be estimated to be $23 \%$ of the $\mathrm{AB}$ (Chojnacky et al., 2014), giving estimates surprisingly close to the measurements, so while our data is very uncertain, using literature based values instead would have had little effect on the overall results.

The contribution of litter and prunings to overall tree $\mathrm{C}$ sequestration appeared large for the still rather small case study trees. However, the literature-based decay factors may not have performed well under our conditions; the contradictory results concerning urban vs. rural litter decomposition rates (Pouyat et al., 1997; Pouyat and Carreiro, 2003; Nikula et al., 2010; Dorendorf et al., 2015) indicate that the processes related to urban litter are not yet well understood. When the soil surface is sealed, the aboveground litter is likely lost from the tree-soil system, warranting leaving it out of the $\mathrm{C}$ sequestration estimates. However, the $\mathrm{C}$ input in leaves was quite high in the case study trees, indicating that improving leaf $\mathrm{C}$ retention and longevity may be one key factor in improving urban tree $\mathrm{C}$ sequestration.

In tree $\mathrm{C}$ sequestration, the favourable growth rate of trees is critical, because biomass is a function of tree size, and tree size growth is dependent on the growing conditions. The uncertainty in tree $\mathrm{C}$ sequestration 
predictions in general is thus mainly linked with the difficulty in predicting tree growth rate and mortality

483 (Strohbach et al., 2012); this is easily seen in the DBH data of existing Tilia plantings in Helsinki (Figure 6).

484 Identifying the remaining original trees and the planting year data was not easy in all cases, which may explain some of the variation. Since the BEs appeared to underestimate branch biomass, the biomass in the prunings was likely also underestimated. This may have been compensated for somewhat, because the pruned branch biomass was not removed from the predicted tree biomass.

In forest ecosystems, trees accumulate $\mathrm{C}$ as they grow, but soil $\mathrm{C}$ dynamics are dependent on litter input and decomposition, which can be affected by disturbances such as tree felling. Research on traditional forest soil C stock temporal dynamics is often contradictory and confounded by the various initial states (e.g. fire, harvest or plantation) of the system (Yang et al., 2011). Similarly, planting of urban trees is usually preceded by a land-use change, making it difficult to draw parallels with native ecosystems; however, there are some studies showing recovery of urban soil C stocks over time (e.g. Golubiewski, 2006; Bae and Ryu, 2015; Setälä et al. 2016). In managed traditional forests of Finland, soil C stock decreases for approximately 20 years after clearcutting (Peltoniemi et al., 2004) but net $\mathrm{C}$ sequestration in the ecosystem can be reached after some 10--15 years (Kolari et al., 2004). The most positive compensation point estimates in this study were similar, yet we must conclude that the often stated expected street tree lifespan of 20--30 years (Roman and Scatena, 2011) appears unlikely to bring tree $C$ sequestration benefits in soil mixes in the study, even if only the entirely peat-originating loss of $\mathrm{C}$ on soil 1 is considered accountable. Fortunately, the annual $\mathrm{C}$

It is also likely that the belowground litter $\mathrm{C}$ input will increase the soil $\mathrm{C}$ stock over time. A pattern of initial soil C loss, followed by soil C stock increase, in conjunction with change to urban land use has been emerging in the USA (Pataki et al. 2006). In our study, soil C loss was high in the beginning, but stabilized after the first few years (Figure 2); it is possible that soil C will start to increase as time passes, paralleling this type of development. The estimates of compensation point timing are thus very uncertain in relation to possible soil $\mathrm{C}$ stock increase over time and must be considered as only suggestions for the minimum tree life expectancy needed to produce net $\mathrm{C}$ sequestration by planting street trees in artificial growth media. The design of our study was not particularly well suited for generalization of the results but rather it demonstrated possible long term $\mathrm{C}$ dynamics in urban planting schemes. There are many $\mathrm{C}$ expenses related to street trees that we are not accounting for, such as C cost of maintenance (McPherson et al. 2015) and cast iron tree grates and trunk guards. Despite these shortcomings, the range of results indicate that the soil C

Both peat and compost derived organic matter are currently used in growth media; the latter appears to be the more sustainable choice, although the sustainability determined is greatly dependent on the assessment 
method chosen (Defra, 2009). The use of peat in composting process adds to the difficulty of choosing suitable tree soil. While high SOM contents have long been considered beneficial for soil quality (Reeves, 1997), perhaps the amount of SOM used in tree soils could be optimized more carefully. Biochar and other e.g. clay-stabilized $\mathrm{C}$ soil additives appear very attractive new options for $\mathrm{C}$ sources in artificial growth media due to their relative stability in comparison to compost (Bolan et al. 2012, Ameloot et al. 2013).

However, the $\mathrm{C}$ cost of tree planting, or the possible lack of C-related overall benefits, should not discourage people from planting street trees. C sequestration is only one of the ecosystem services provided by trees, and its value is usually estimated to be small in comparison to storm water management, property value and energy-saving benefits, not to mention recreational and cultural values and human health benefits (McPherson et al., 2005). Rather, these results should encourage more investment and interest in tree planning, establishment and maintenance to ensure improvements in urban tree lifespan and eventual tree $\mathrm{C}$ sequestration. Overall, using local soils and less and lighter infrastructure in tree plantings would likely lead to higher net $\mathrm{C}$ sequestration. Unfortunately, these appear to be a rare option in the midst of efforts towards more efficient urban land use.

\section{Conclusions}

535 In considering the $\mathrm{C}$ sequestration capacity of street trees, the initial $\mathrm{C}$ losses from peat-containing soils after site establishment should not be overlooked. Due to the exponential nature of the increase in tree $\mathrm{C}$ stock over time, tree planting-related $\mathrm{C}$ expenses are best compensated for with a long tree life expectancy. This is best achieved with adequate consideration of tree growth requirements over their entire life cycle.

539 Compensating for the smallest measured single tree soil C stock loss of $100 \mathrm{~kg}$ by $\mathrm{C}$ sequestration of the tree 540 in this case study was predicted to require at least 30 years. This exceeds current estimates of average street

541 tree lifespan. Especially the estimates of tree root $\mathrm{C}$ stock and soil $\mathrm{C}$ development in the future were uncertain however.

544 Further research on biomass distribution within urban trees, both above and under ground, is needed to 545 improve the accuracy of urban $\mathrm{C}$ stock and $\mathrm{C}$ stock change estimates. The use of traditional forest based BEs 546 for urban trees may lead to errors when specific $\mathrm{AB}$ compartments are estimated. This causes further 547 problems in assessment of the effects of leaf litter and prunings in urban tree $\mathrm{C}$ sequestration. Cutting the $\mathrm{C}$ 548 expenses of the tree planting and focusing on the longevity of pruning and leaf litter $\mathrm{C}$ may aid in balancing tree-related $\mathrm{C}$ effects. 
552 The research sites were established in collaboration with the City of Helsinki Public Works Department. This 553 work was in part financed by the Maj and Tor Nessling Foundation, Finnish Cultural Foundation and the 554 Academy of Finland's Centre of Excellence (grant no. 272041). Topi Tanhuanpää, Minna Terho and Juha 555 Raisio provided tree DBH data for the study. We thank Erkki Siivola, Janne Järvinen and numerous 556 University of Helsinki forestry MSc students for help with instrument maintenance and data collection. We further thank the anonymous reviewers for their valuable comments.

\section{References}

560 Alden, H.A., 1995. Hardwoods of North America. General Technical Report-Forest Products Laboratory, USDA Forest Service, (FPL-GTR-83).

Ameloot, N., Graber, E. R., Verheijen, F. G., De Neve, S. 2013. Interactions between biochar stability and soil organisms: review and research needs. European Journal of Soil Science 64, 379-390.

Bae, J., Ryu, Y. 2015. Land use and land cover changes explain spatial and temporal variations of the soil organic carbon stocks in a constructed urban park. Landscape and Urban Planning 136, 57-67.

Baskerville, G. L., 1972. Use of logarithmic regression in the estimation of plant biomass. Canadian Journal of Forest Research 2, 49-53.

Bernal, M.P., Sanchez-Monedero, M.A., Paredes, C., Roig, A., 1998. Carbon mineralization from organic wastes at different composting stages during their incubation with soil. Agriculture, Ecosystems \& Environment 69, 175-189.

Bolan, N.S., Kunhikrishnan, A., Choppala, G.K., Thangarajan, R., Chung, J. W., 2012. Stabilization of carbon in composts and biochars in relation to carbon sequestration and soil fertility. Science of the Total Environment 424, 264-270.

Bomberg, M., Timonen, S. 2009. Effect of tree species and mycorrhizal colonization on the archaeal population of boreal forest rhizospheres. Applied and environmental microbiology, 75, 308-315.

583 Brenneman, B.B., Gardner, W.E., Schoenhofen, L.H., Marsh, P.L., 1978. Biomass of species and stands of 584 West Virginia hardwoods. In: Proceedings of Central Hardwood Forest Conference II (ed. Pope, P.E.). West Lafayette, Purdue University. 
Browaldh, M., 1997. Nitrogen release from leaves and prunings of different tree species used as green manures. Biological Agriculture \& Horticulture 14, 309-322.

Bunce, R.G.H., 1968. Biomass and production of trees in a mixed deciduous woodland. I. Girth and height as parameters for the estimation of tree dry weight. Journal of Ecology 56, 759-775.

Böckmann, T., 1990. Ertragstafel für Winterlinde (Tilia cordata Mill.) in Niedersachsen und Nordhessen. Allgemeine Forst- und Jagdzeitung 162, 28-34.

Chojnacky, D.C., Heath, L.S., Jenkins, J.C., 2014. Updated generalized biomass equations for North American tree species. Forestry 87, 129-151.

Day, S.D., Wiseman, E., Dickinson, S.B., Harris J.R., 2010. Contemporary concepts of root system architecture of urban trees. Arboriculture \& Urban Forestry 364, 149-159.

Defra, 2009. A preliminary assessment of the greenhouse gases associated with growing media materials. IFO154. Research Final Report. SID 5. http://randd.defra.gov.uk. Retrieved 05/2015.

Dilly, O., Munch, J.-C., 1996. Microbial biomass content, basal respiration and enzyme activities during the course of decomposition of leaf litter in black alder (Alnus glutinosa (L.) Gaertn.) forest. Soil Biology and

Dorendorf, J., Wilken, A., Eschenbach, A., Jensen, K., 2015. Urban-induced changes in tree leaf litter accelerate decomposition. Ecological Processes 4, 1-16.

612 Golubiewski, N. E., 2006. Urbanization increases grassland carbon pools: Effects of landscaping in 613 Colorado's front range. Ecological Applications 16, 555-571.

615 Grabosky, J., Bassuk, N., 1995. A new urban tree soil to safely increase rooting volumes under sidewalks. Journal of Arboriculture 21, 187-187.

Hobbie, S.E., Reich, P.B., Oleksyn, J., Ogdahl, M., Zytkowiak, R., Hale, C., Karolewski, P., 2006. Tree species effects on decomposition and forest floor dynamics in a common garden. Ecology 87, 2288-2297. carbon through loss on ignition: effects of ignition conditions and structural water loss. European Journal of 
625 Hughes, M.K., 1971. Tree biocontent, net production and litter fall in a deciduous woodland. Oikos 22, 6262673.

627 Himanen, M., Hänninen, K. 2011. Composting of bio-waste, aerobic and anaerobic sludges-ludges, aerobic and anaerobic sludgesdeciduous woodland. OiBioresource technology 102, 2842-2852.

IPCC 2006, 2006 IPCC Guidelines for National Greenhouse Gas Inventories, Prepared by the National

631 Greenhouse Gas Inventories Programme, Eggleston H.S., Buendia L., Miwa K., Ngara T., and Tanabe K. 632 (eds). Published: IGES, Japan. loam soil. Agricultural and Food Science in Finland 7, 491-505.

Johansson, T., 1999. Dry matter amounts and increment in 21- to 91-year-old common alder and grey alder and some practical implications. Canadian Journal of Forest Research 29, 1679-1690.

Johansson, T,. 2000. Biomass equations for determining functions of common and grey alder growing on abandoned farmland and some practical implications. Biomass and Bioenergy 18, 147-159. aged Scots pine forests in southern Finland. Global Change Biology 10, 1106-1119.

Kornelsen, K., Coulibaly, P., 2012. Comparison of interpolation, statistical, and data-driven methods for imputation of missing values in a distributed soil moisture dataset. Journal of Hydrologic Engineering 19, 26-43.

Kristoffersen, P., 1999. Growing trees in road foundation materials. Arboricultural Journal 23, 57-76. 
659 Liski, J., Lehtonen, A., Palosuo, T., Peltoniemi, M., Eggers, T., Muukkonen, P., and Mäkipää, R., 2006.

660 Carbon accumulation in Finland's forests 1922-2004 - an estimate obtained by combination of forest

661 inventory data with modelling of biomass, litter and soil. Annals of Forest Science 63, 687-697.

662

663 Litton, C.M., Raich, J.W., Ryan, M.G,. 2007. Carbon allocation in forest ecosystems. Global Change

664 Biology 13, 2089-2109.

665

666 McHale M., Burke, I., Lefsky, M., Peper, P., McPherson, E., 2009. Urban forest biomass estimates: is it 667 important to use allometric relationships developed specifically for urban trees? Urban Ecosystems 12, 95-

668113.

669

McPherson, E. G., Kendall, A., Albers, S., 2015. Life cycle assessment of carbon dioxide for different arboricultural practices in Los Angeles, CA. Urban Forestry \& Urban Greening 14, 388-397.

McPherson, G., Simpson, J.R., Peper, P.J., Maco, S.E., \& Xiao, Q., 2005. Municipal forest benefits and costs in five US cities. Journal of Forestry 103, 411-416.

Neal, B.A., Whitlow, T.H., 1997. Using tree growth rates to evaluate urban tree planting specifications.

Niinemets, Ü., 1999. Energy requirement for foliage formation is not constant along canopy light gradients in temperate deciduous trees. New Phytologist 141, 459-470.

Nikula, S., Vapaavuori, E., \& Manninen, S., 2010. Urbanization-related changes in European aspen (Populus

Olson, J.S., 1963. Energy storage and the balance of producers and decomposers in ecological systems.

Pataki, D.E., Alig, R.J., Fung, A.S., Golubiewski, N.E., Kennedy, C.A., McPherson, E.G., Nowak, D.J., 
Peper, P.J., Alzate, C.P., McNeil, J.W. , Hashemi, J., 2014. Allometric equations for urban ash trees (Fraxinus spp.) in Oakville, Southern Ontario, Canada, Urban Forestry \& Urban Greening 13, 175-183.

Perala D,A., Alban D.H., 1994. Allometric biomass estimators for Aspen-dominated ecosystems in the upper Great Lakes. Research Paper NC-314. USDA Forest Service, North Central Experiment Station, St. Paul, MN.

\section{Perruchould, D., Joos, F., Fischlin, A., Hajdas, I., Bonani, G., 1999. Evaluating timescales of carbon} turnover in temperate forest soils with radiocarbon data. Global Biogeochemical Cycles 13, 555-573.

Pouyat, R.V., Carreiro, M.M., 2003. Controls on mass loss and nitrogen dynamics of oak leaf litter along an urban-rural land-use gradient. Oecologia 135, 288-298.

Pouyat, R.V., McDonnell, M.J., Pickett, S.T., 1997. Litter decomposition and nitrogen mineralization in oak stands along an urban-rural land use gradient. Urban Ecosystems 1, 117-131.

Prasad, M., Maher, M.J., 2003. Stability of peat alternatives and use of moderately decomposed peat as a structure builder in growing media. In: South Pacific Soilless Culture Conference-SPSCC 648, pp. 145-151.

Prasad, M., O'Shea, J., 1997. Relative breakdown of peat and non-peat growing media. In: International Symposium on Growing Media and Hydroponics 481, pp. 121-128.

Pregitzer, K.S., Euskirchen, E.S., 2004. Carbon cycling and storage in world forests: biome patterns related to forest age. Global Change Biology 10, pp. 2052-2077.

Rakennustietosäätiö RTS, 2010. InfraRYL 2010, infrarakentamisen yleiset laatuvaatimukset 2010 (Quality guidelines of infrastructure construction; language Finnish). Osa 1, Väylät ja alueet. Helsinki: Rakennustieto, 2010.

Reeves, D. W., 1997. The role of soil organic matter in maintaining soil quality in continuous cropping systems. Soil and Tillage Research 43, 131-167.

Riikonen, A., Lindén, L., Pulkkinen, M., Nikinmaa, E.,. 2011. Post-transplant crown allometry and shoot growth of two species of street trees. Urban Foresty \& Urban Greening 10, 87-94.

Roman, L.A., Scatena, F.N. 2011. Street tree survival rates: Meta-analysis of previous studies and application to a field survey in Philadelphia, PA, USA. Urban Forestry \& Urban Greening 10, 269-274. 
733 Sanchez-Monedero, M.A., Mondini, C., De Nobili, M., Leita, L., Roig, A. 2004. Land application of 734 biosolids. Soil response to different stabilization degree of the treated organic matter. Waste Management $73524,325-332$.

Scalenghe, R., Marsan, F.A., 2009. The anthropogenic sealing of soils in urban areas. Landscape and Urban Planning 90, 1-10.

Schober, R., 1987. Ertragstafeln wichtiger Baumarten bei verschiedener Durchforstung. J.D. Dauerländer's Verlag, Frankfurt am Main, Germany, 166 p. In German.

Setälä, H. M., Francini, G., Allen, J. A., Hui, N., Jumpponen, A., Kotze, D. J., 2016. Vegetation type and age drive changes in soil properties, nitrogen, and carbon sequestration in urban parks under cold climate. Frontiers in Ecology and Evolution 4, 93.

Strohbach, M.W., Arnold, E., Haase, D., 2012. The carbon footprint of urban green space - A life cycle approach. Landscape and Urban Planning 104, 220-229.

Taubner, H., Roth, B., Tippkötter, R., 2009. Determination of soil texture: Comparison of the sedimentation method and the laser-diffraction analysis. Journal of Plant Nutrition and Soil Science 172, 161-171.

Ter-Mikaelian, M.T., Korzukhin, M.D., 1997. Biomass equations for sixty-five North American tree species. Forest Ecology and Management 97, 1-24 dynamics in soils reconstituted with large quantities of organic matter. European Journal of Soil Science 63, 787-797.

Williams, M. A., Rice, C. W. 2007. Seven years of enhanced water availability influences the physiological, 762 structural, and functional attributes of a soil microbial community. Applied Soil Ecology, 35, 535-545. 
766 Zhou, X., Schoeneberger, M.M., Brandle, J.R., Awada, T.N., Chu, J., Martin, D.L., Li, J., Li, Y., Mize,

767 C.W., 2014. Analyzing the uncertainties in use of forest-derived biomass equations for open-grown trees in 768 agricultural land. Forest Science 61, 144-161.

769 
770 Table 1. A summary of major measurements performed for the case study (Tilia and Alnus sites in 2003-

771 2011), and numbers of samples taken and/or analyzed, at Tilia and Alnus sites. $\mathrm{T}=$ temperature $\left({ }^{\circ} \mathrm{C}\right) \mathrm{D}=$

772 diameter $(\mathrm{mm}), \mathrm{BM}=$ biomass $(\mathrm{g})$.

773

\begin{tabular}{|c|c|c|c|c|c|c|c|c|}
\hline & \multicolumn{4}{|c|}{ Soils } & \multicolumn{4}{|c|}{ Trees } \\
\hline $\begin{array}{l}\text { Site } \\
\text { and } \\
\text { measu- } \\
\text { rement }\end{array}$ & $\begin{array}{l}\mathrm{T}_{\mathrm{f}} \text { (every } \\
30 \mathrm{~min})\end{array}$ & $\begin{array}{l}\mathrm{W}_{\mathrm{f}} \text { (every } \\
30 \mathrm{~min})\end{array}$ & $\begin{array}{l}\text { LOI, loose } \\
\mathrm{BD}, \\
\text { particle } \\
\text { size } \\
\text { distribution }\end{array}$ & $\begin{array}{l}\mathrm{T}, \mathrm{SWC}, \\
\mathrm{LOI} \\
\text { response } \\
\text { of } \mathrm{CO}_{2} \\
\text { production }\end{array}$ & $\begin{array}{l}\text { Trunk } \\
\text { and } \\
\text { branch } \\
\text { D }\end{array}$ & $\begin{array}{l}\text { Leaf } \\
\text { area }\end{array}$ & $\begin{array}{l}\text { Prunings } \\
\text { (BM and } \\
\mathrm{D} / \mathrm{BM} \\
\text { ratio) }\end{array}$ & $\begin{array}{l}\text { Root } \\
\text { BM }\end{array}$ \\
\hline $\begin{array}{l}\text { Tilia } \\
\text { site }\end{array}$ & $\begin{array}{l}2003-2011, \\
3 \text { sensors at } \\
30,60 \text {, and } \\
90 \mathrm{~cm} \\
\text { depth, } \\
\text { respectively }\end{array}$ & $\begin{array}{l}2003-2011, \\
3 \text { sensors at } \\
30 \text { and } 60 \\
\text { cm depth, } \\
\text { respectively }\end{array}$ & $\begin{array}{l}2005 \\
(\mathrm{n}=6), \\
2008 \\
(\mathrm{n}=15), \\
2011 \\
(\mathrm{n}=12)\end{array}$ & $\begin{array}{l}2005 \\
(n=6), \\
2008 \\
(n=12), \\
2011 \\
(n=12)\end{array}$ & $\begin{array}{l}2005 \\
(n=8), \\
2008 \\
(n=7), \\
2011 \\
(n=6)\end{array}$ & $\begin{array}{l}2004- \\
2011 \\
(\mathrm{n}=6-12 \\
\text { trees, } 3 \\
\text { branches } \\
\text { per tree) }\end{array}$ & $\begin{array}{l}\text { Every } \\
\text { time trees } \\
\text { were } \\
\text { pruned. } \\
(2008- \\
2011 \text {, } \\
n=7)\end{array}$ & $\begin{array}{l}2005, \\
2008, \\
2011 \\
(n=6)\end{array}$ \\
\hline $\begin{array}{l}\text { Alnus } \\
\text { site }\end{array}$ & $\begin{array}{l}2003-2011, \\
3 \text { sensors at } \\
30,60 \text {, and } \\
90 \mathrm{~cm} \\
\text { depth, } \\
\text { respectively }\end{array}$ & $\begin{array}{l}2003-2011, \\
3 \text { sensors at } \\
30 \text { and } 60 \\
\text { cm depth, } \\
\text { respectively }\end{array}$ & $\begin{array}{l}2005 \\
(\mathrm{n}=6), \\
2008 \\
(\mathrm{n}=15), \\
2011 \\
(\mathrm{n}=12)\end{array}$ & $\begin{array}{l}2005 \\
(n=6), \\
2008 \\
(n=12), \\
2011 \\
(n=12)\end{array}$ & $\begin{array}{l}2005 \\
(n=10), \\
2008 \\
(n=7), \\
2011 \\
(n=6)\end{array}$ & $\begin{array}{l}2004- \\
2011 \\
(n=6-12 \\
\text { trees, } 3 \\
\text { branches } \\
\text { per tree) }\end{array}$ & $\begin{array}{l}\text { Whenever } \\
\text { pruned } \\
(2010 \text {, } \\
n=11)\end{array}$ & $\begin{array}{l}2005, \\
2008, \\
2011 \\
(n=6)\end{array}$ \\
\hline
\end{tabular}

Table 2. Details of the DBH growth and biomass $\mathrm{C}$ accumulation forecast models. BE s (biomass equations) referred can be found in the Appendix.

\begin{tabular}{llll}
\hline & Forecast 1 for Tilia & Forecast 2 for Tilia & Forecast 1 for Alnus \\
\hline DBH growth forecast & & & \\
\hline & Street trees (Larsen and & Traditional forest trees & $\begin{array}{l}\text { Traditional forest trees } \\
\text { (Yield class III, Schober, } \\
\end{array}$ \\
& Kristoffersen, 2002) & Böckmann, 1990) & 1987) \\
\hline
\end{tabular}

Biomass accumulation by compartment 


\begin{tabular}{lll}
\hline Roots & $\begin{array}{l}\text { 23\% of aboveground } \\
\text { woody biomass } \\
\text { (Chojnacky et al., 2014) }\end{array}$ & $\begin{array}{l}\text { 23\% of aboveground } \\
\text { woody biomass } \\
\text { (Chojnacky } \text { et al., 2014) }\end{array}$ \\
\hline
\end{tabular}

\section{Litter}

\begin{tabular}{|c|c|c|}
\hline Leaf & $\mathrm{BE} 3 \mathrm{~b}$ & $\mathrm{BE} 7 \mathrm{~b}$ \\
\hline Branch (prunings) & $\mathrm{BE} 3 \mathrm{c}$ & $\mathrm{BE} 5 \mathrm{~b}$ \\
\hline $\begin{array}{l}\text { Decay function; } \\
\text { parameters (leaves, } \\
\text { branches) }\end{array}$ & $\begin{array}{l}\text { Olson 1963; } 0.24 \text { (Hobbie } \\
\text { et al., 2006), } 0.22 \\
\text { (Perruchould } \text { et al., 1999) }\end{array}$ & $\begin{array}{l}\text { Olson 1963; } 0.60 \text { (Dilly } \\
\text { and Munch, 1996), 0.22 } \\
\text { (Perruchould } \text { et al., 1999) }\end{array}$ \\
\hline
\end{tabular}

778 Table 3. Parameter values $\pm \mathrm{SD}, \mathrm{R}^{2}$ and White's heteroscedasticity test $\mathrm{p}$-value for soil and site specific $\mathrm{P}$ 779 prediction models (Eq. 4). The parameters $\lambda$ (intercept), $\alpha$ (SW and LOI parameter), and $\beta$ (temperature 780 response parameter) were used to predict C loss (Eq. 5).

\begin{tabular}{|c|c|c|c|c|c|c|}
\hline Site & Soil mix & $\lambda$ & $\alpha$ & $\beta$ & Adj. $R^{2}$ & $\begin{array}{l}\text { White's test p- } \\
\text { value }\end{array}$ \\
\hline \multirow[t]{3}{*}{ Tilia } & 1 & $\begin{array}{c}-18.02 \pm \\
0.68\end{array}$ & $\begin{array}{c}0.083 \pm \\
0.013\end{array}$ & $\begin{array}{c}0.08 \pm \\
0.149\end{array}$ & 0.51 & 0.19 \\
\hline & 2 & $\begin{array}{c}-19.43 \pm \\
0.64\end{array}$ & $\begin{array}{c}0.083 \pm \\
0.011\end{array}$ & $\begin{array}{l}0.44 \pm \\
0.078\end{array}$ & 0.68 & 0.57 \\
\hline & 3 & $\begin{array}{c}-17.81 \pm \\
0.17\end{array}$ & $\begin{array}{c}0.065 \pm \\
0.008\end{array}$ & $\begin{array}{c}0.34 \pm \\
0.083\end{array}$ & 0.65 & 0.08 \\
\hline \multirow[t]{3}{*}{ Alnus } & 1 & $\begin{array}{c}-19.16 \pm \\
0.21\end{array}$ & $\begin{array}{c}0.084 \pm \\
0.011\end{array}$ & $\begin{array}{l}0.48 \pm \\
0.083\end{array}$ & 0.71 & 0.43 \\
\hline & 2 & $\begin{array}{c}-18.70 \pm \\
0.26\end{array}$ & $\begin{array}{c}0.108 \pm \\
0.008\end{array}$ & $\begin{array}{c}0.16 \pm \\
0.034\end{array}$ & 0.84 & 0.82 \\
\hline & 3 & $\begin{array}{c}-18.91 \pm \\
0.14\end{array}$ & $\begin{array}{c}0.090 \pm \\
0.006\end{array}$ & $\begin{array}{c}0.67 \pm \\
0.142\end{array}$ & 0.85 & 0.50 \\
\hline
\end{tabular}


Table 4. Estimated C in the Tilia and Alnus aboveground stem, branch, roots and total C in woody biomass; cumulative original C in leaves and pruned

$\mathrm{C}$ in the leaves and branches was calculated for each cohort separately and summed up. ABW = aboveground woody biomass.

\begin{tabular}{|c|c|c|c|c|c|c|c|c|c|c|}
\hline & Year & Stem & Branches & ABW & Roots & $\begin{array}{c}\text { Total } \\
\text { woody }\end{array}$ & $\begin{array}{l}\text { Leaf C } \\
\text { remaining }\end{array}$ & $\begin{array}{c}\text { Prunings C } \\
\text { remaining }\end{array}$ & $\begin{array}{c}\text { Total litter }+ \\
\text { prunings }\end{array}$ & Sum \\
\hline \multirow{5}{*}{$\stackrel{\Xi}{*}$} & At planting & $\mathrm{n} / \mathrm{a}$ & $\mathrm{n} / \mathrm{a}$ & $6.7^{*}$ & 0.2 & $6.9 *$ & 0 & 0 & 0 & $6.9^{*}$ \\
\hline & 2005 & $2.5 \pm 0.4$ & $2.3 \pm 0.6$ & $4.9 \pm 0.9$ & $\mathrm{n} / \mathrm{a}$ & $6.3 * *$ & 1.5 & 0 & 1.5 & $7.8^{* *}$ \\
\hline & 2008 & $5.4 \pm 2.1$ & $4.1 \pm 2.1$ & $9.5 \pm 4.0$ & $3.4 \pm 5.2$ & 12.9 & 3.9 & 0 & 3.9 & 16.8 \\
\hline & 2011 & $8.4 \pm 4.1$ & $8.2 \pm 2.8$ & $16.6 \pm 6.7$ & $8.5 \pm 9.7$ & 25.1 & 7.3 & 0.6 & 7.9 & 33.0 \\
\hline & $\mathrm{C}$ stock increase & $\mathrm{n} / \mathrm{a}$ & $\mathrm{n} / \mathrm{a}$ & 9.9 & 8.3 & 18.2 & 7.3 & 0.6 & 7.9 & 26.1 \\
\hline \multirow{5}{*}{ 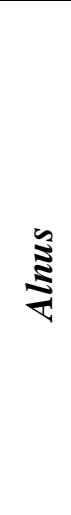 } & At planting & $\mathrm{n} / \mathrm{a}$ & $\mathrm{n} / \mathrm{a}$ & $5.6^{*}$ & 0.1 & $5.7 \dagger$ & 0 & 0 & 0 & $5.7^{*}$ \\
\hline & 2005 & $4.2 \pm 0.8$ & $2.9 \pm 0.6$ & $7.1 \pm 1.3$ & $\mathrm{n} / \mathrm{a}$ & $9.2 * *$ & 2.1 & 0 & 2.1 & $11.3^{* *}$ \\
\hline & 2008 & $8.2 \pm 1.3$ & $6.9 \pm 1.5$ & $15.1 \pm 1.0$ & $3.1 \pm 4.1$ & 16.5 & 3.8 & 0 & 3.8 & 22.0 \\
\hline & 2011 & $17.6 \pm 2.8$ & $12.6 \pm 2.7$ & $30.2 \pm 4.3$ & $7.3 \pm 7.1$ & 36.0 & 6.3 & 0.1 & 6.3 & 43.9 \\
\hline & $\mathrm{C}$ stock increase & $\mathrm{n} / \mathrm{a}$ & $\mathrm{n} / \mathrm{a}$ & 24.6 & 7.2 & 31.8 & 6.3 & 0.1 & 6.3 & 38.2 \\
\hline
\end{tabular}

$791 * *$ Root biomass estimated as $23 \%$ of ABW (Chojnacky et al., 2014) added to total woody biomass 
793 Table 4. Biomass of the various tree compartments as measured ( $\mathrm{kg}$ per tree $\pm \mathrm{SD}, \mathrm{n}=6-12$ ) and predicted 794 from the DBH with biomass equations (average of the trees included in the biomass measurements) for each 795 taxon in 2011. The number and letter in superscript indicate the equation used (Appendix). ABW =

796 aboveground woody biomass, $\mathrm{AB}=$ aboveground biomass, including leaves. * denotes that the biomass 797 model prediction is significantly different from the measurement results (Tukey's 2-sided t-test).

\begin{tabular}{llllll}
\hline & Stem & Branch & Leaf & ABW & AB \\
\hline Tilia meas. & $18.6 \pm 9.1$ & $18.2 \pm 6.2$ & $4.5 \pm 1.0$ & $36.8 \pm 14.9$ & $41.3 \pm 15.3$ \\
\hline Tilia pred. & $36.1 \pm 13.5^{* 3 \mathrm{~d}+3 \mathrm{e}}$ & $7.5 \pm 3.2^{* 3 \mathrm{~d}}$ & $1.4 \pm 0.5^{* 3 \mathrm{~b}}$ & $\begin{array}{l}43.2 \pm 17.0^{1}, \\
79.3 \pm 26.4^{* 4}\end{array}$ & $\begin{array}{l}47.8 \pm 19.4^{2} \\
42.0 \pm 15.9^{3 \mathrm{a}}\end{array}$ \\
\hline Alnus meas. & $39.1 \pm 6.3$ & $28.0 \pm 5.9$ & $6.8 \pm 1.3$ & $67.1 \pm 9.6$ & $73.9 \pm 10.8$ \\
\hline & & & & $48.0 \pm 5.6^{* 5 \mathrm{a}}$ & \\
& $61.0 \pm 7.4^{* 5 \mathrm{c}}$ & $12.8 \pm 1.6^{* 5 \mathrm{~b}}$ & $1.0 \pm 0.1^{* 6 \mathrm{~b}}$ & $73.7 \pm 8.9^{5 \mathrm{~b}+\mathrm{c}}$ & $74.5 \pm 7.4^{6 \mathrm{a}}$ \\
Alnus pred. & $69.3 \pm 6.4^{* 6 \mathrm{~d}}$ & $5.3 \pm 0.7^{* 6 \mathrm{c}}$, & $1.8 \pm 0.1^{* 7 \mathrm{~b}}$ & $73.5 \pm 7.3^{6 \mathrm{a} \mathrm{b}}$ & $70.9 \pm 8.0^{7 \mathrm{a}}$ \\
& $60.7 \pm 6.5^{* 7 \mathrm{~d}}$ & $7.8 \pm 1.3^{* 7 \mathrm{c}}$ & & $69.1 \pm 7.8^{7 \mathrm{ab}}$ & \\
& & & & &
\end{tabular}




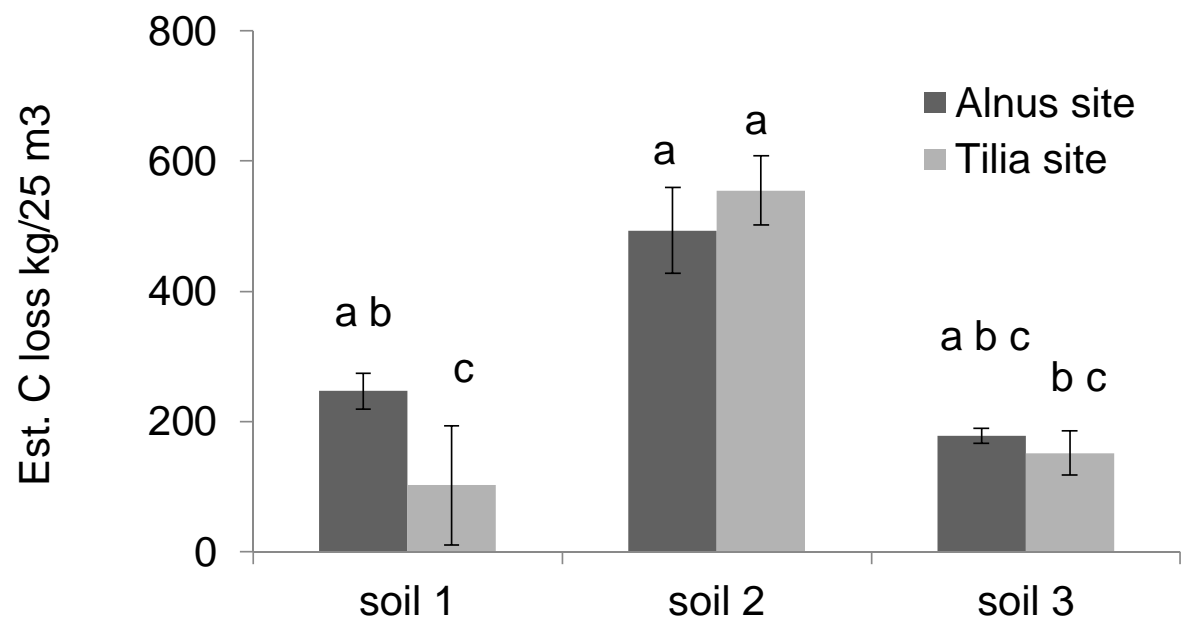

800

801 Figure 1. Estimates of cumulative $C$ loss $( \pm \mathrm{SD})$ estimated per the $25 \mathrm{~m}^{3}$ of the three different tested tree 802 soils from 2002 to 2011 , based on the soil loss-on-ignition change. The mean values indicated with the same 803 letter do not differ significantly.

804

805

806

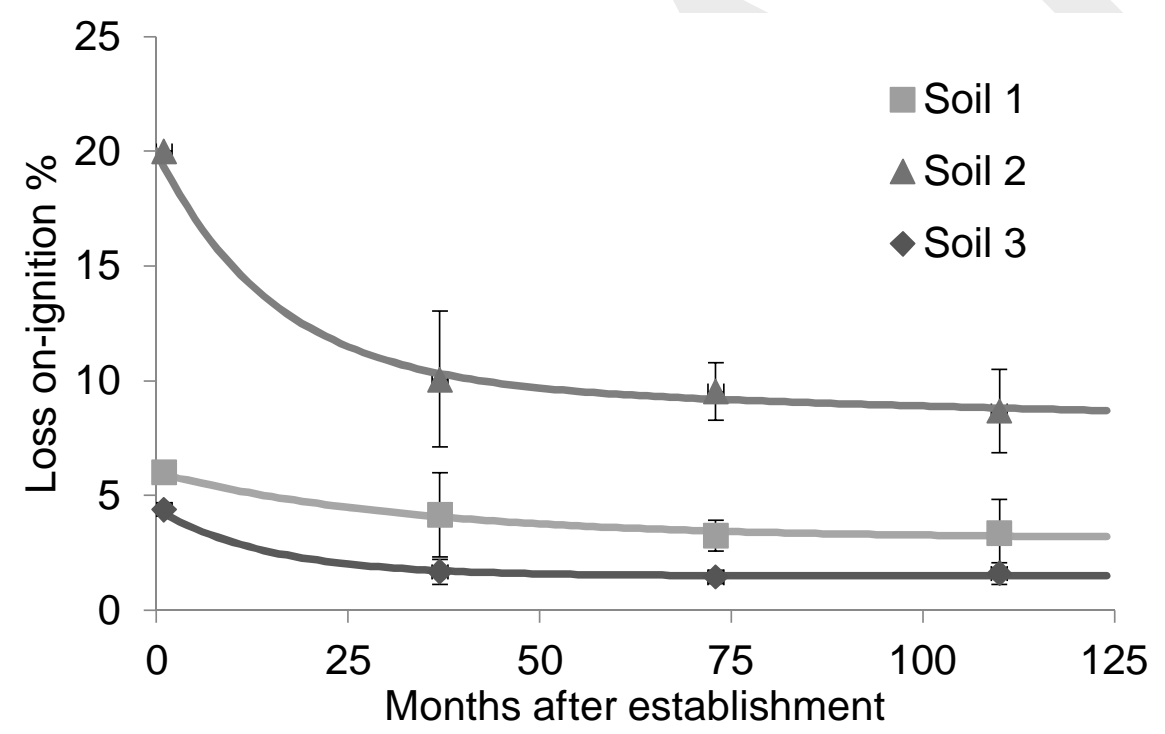

808 Figure 2. Initial and measured average loss-on-ignition ( \pm SD) for each soil mix fine soil fraction at each 809 sampling time (markers), and estimates for LOI between LOI sampling from the incubation model $\left(O_{e}\right)$ 810 (lines, Eq. 6) for each month after establishment. 


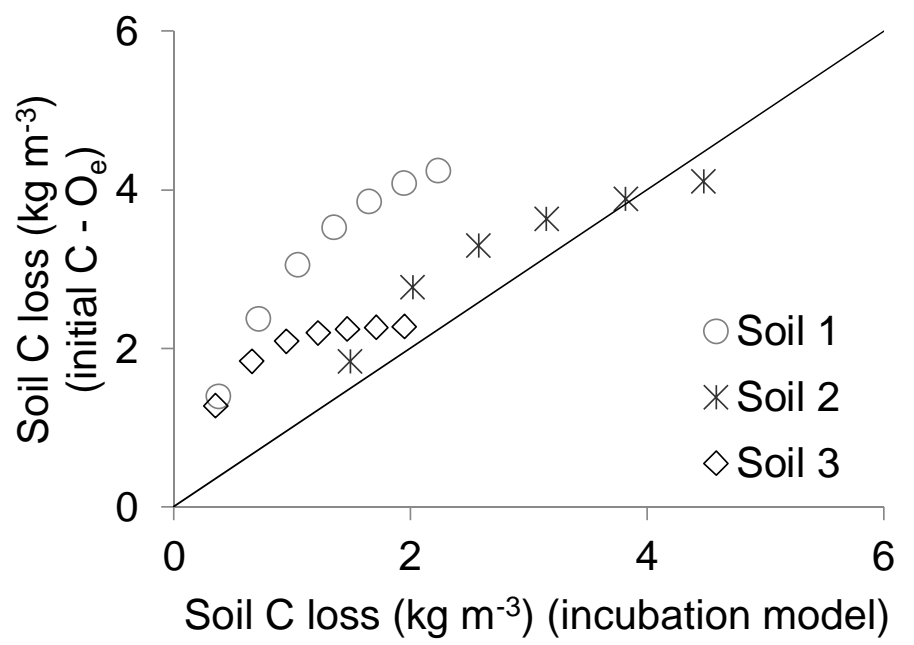

812

Figure 3. Cumulative $\mathrm{C}$ loss in 2006-2011, based on the $\mathrm{O}_{\mathrm{e}}$ value (Eq. 6; Figure 2) on the $\mathrm{X}$ axis and the incubation model on the $\mathrm{Y}$ axis, with early 2005 as the starting point.

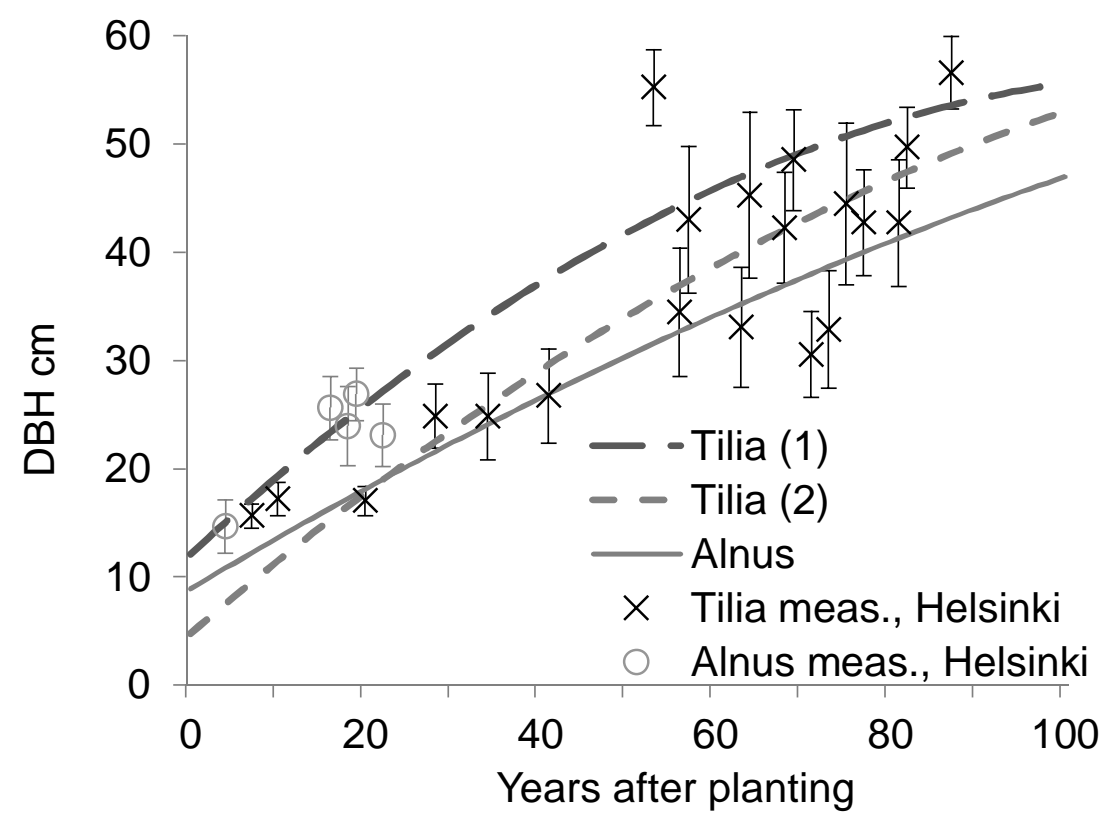

Figure 6. Measured and predicted DBHs for Tilia and Alnus. The DBH predictions, two for Tilia and one for Alnus, are based on literature (see Table 2). The crosses mark the average DBHs measured from the street tree Tilia plantings in Helsinki ( \pm standard deviation, SD) plotted against the number of years after planting. The average DBH ( \pm SD) of the two known older Alnus glutinosa f. pyramidalis plantings in Helsinki, for one at two and for the other at three available time points, are marked with circles. Average predicted DBH growth rates at $0-20$ years, $0.65,0.69$, and $0.46 \mathrm{~cm} \mathrm{yr}^{-1}$, at 20-40 years, $0.57,0.56$ and $0.42 \mathrm{~cm} \mathrm{yr}^{-1}$, and $>40$ years, $0.40,0.31$ and $0.34 \mathrm{~cm} \mathrm{yr}^{-1}$ for Tilia predictions 1 and 2, and Alnus prediction, respectively. 


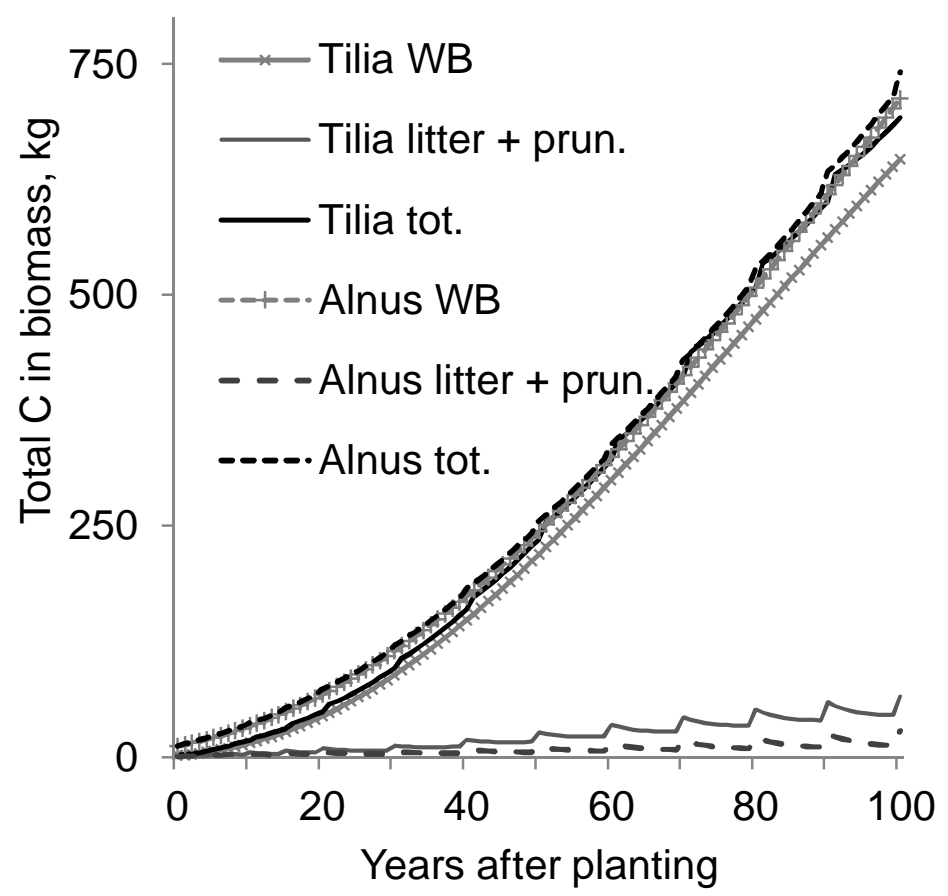

826 827 828 829 830 831 


\section{Appendix.}

833 Parameters and references for the allometric equations (BEs) for the total $\mathrm{AB}$ and branch, trunk and leaf

834 biomass used in the calculations in this study. Equations 1--4 are for Tilia sp. and 5--7 for Alnus glutinosa.

835 The DBH ranges for which the equation was developed are listed. The equation form is $\mathrm{M}=\mathrm{aD}$, where $\mathrm{M}=$ 836 biomass $(\mathrm{kg})$ and $\mathrm{D}=\mathrm{DBH}$, unless noted otherwise.

\begin{tabular}{|c|c|c|c|c|c|c|}
\hline & $\begin{array}{l}\text { Allom. } \\
\text { equation no. }\end{array}$ & Parameter $a$ & parameter $b$ & $\begin{array}{c}\text { Biomass } \\
\text { compartment }\end{array}$ & $\begin{array}{c}\text { DBH range and } \\
\text { unit }\end{array}$ & Reference \\
\hline \multirow{8}{*}{$\begin{array}{c}T \\
i l \\
i \\
a\end{array}$} & 1 & -5.49 & 2.45 & woody abovegr.* & $3--15 \mathrm{~cm}$ & Bunce, $1968 \dagger$ \\
\hline & 2 & 0.062 & 2.53 & total abovegr. & $5--50 \mathrm{~cm}$ & $\begin{array}{c}\text { Brenneman, } \\
\text { 1978, ref. Ter- } \\
\text { Mikaelian and } \\
\text { Korzukhin, } 1997 \\
\quad+\dagger\end{array}$ \\
\hline & $3 a$ & 0.087 & 2.35 & total abovegr. & \multirow{5}{*}{$4--47 \mathrm{~cm}$} & \multirow{5}{*}{$\begin{array}{c}\text { Perala and } \\
\text { Alban, } 1994 \dagger \dagger\end{array}$} \\
\hline & $3 b$ & $4.90 \times 10^{-3}$ & 2.09 & Leaves $\$$ & & \\
\hline & $3 c$ & $6.59 \times 10^{-3}$ & 2.68 & branches & & \\
\hline & $3 d$ & $4.99 \times 10^{-2}$ & 2.40 & stem wood & & \\
\hline & $3 e$ & $4.32 \times 10^{-2}$ & 2.03 & stem bark & & \\
\hline & 4 & $9.40 \times 10^{-2}$ & 2.04 & woody abovegr.** & $\mathrm{n} / \mathrm{a}, \mathrm{cm}$ & $\begin{array}{l}\text { McHale et al., } \\
2009 \dagger\end{array}$ \\
\hline \multirow{11}{*}{$\begin{array}{l}A \\
l \\
n \\
u \\
s\end{array}$} & $5 \mathrm{a}$ & $8.60 \times 10^{-2}$ & 2.35 & woody abovegr. & \multirow{3}{*}{$\mathrm{n} / \mathrm{a}, \mathrm{cm}$} & \multirow{3}{*}{ Hughes, 1971} \\
\hline & $5 b$ & $1.47 \times 10^{-2}$ & 2.52 & branches & & \\
\hline & $5 c$ & $8.42 \times 10^{-2}$ & 2.45 & stem & & \\
\hline & $6 a$ & $3.09 \times 10^{-3}$ & 2.02 & total abovegr. & \multirow{4}{*}{$120--280 \mathrm{~mm}$} & \multirow{4}{*}{ Johansson, 1999} \\
\hline & $6 \mathrm{~b}$ & $3 \times 10^{-6}$ & 2.55 & leaves & & \\
\hline & $6 c$ & $3 \times 10^{-6}$ & 2.88 & branches & & \\
\hline & $6 \mathrm{~d}$ & $5.61 \times 10^{-3}$ & 1.89 & stem & & \\
\hline & $7 \mathrm{a}$ & $7.90 \times 10^{-4}$ & 2.29 & total abovegr. & \multirow{4}{*}{ 20--170 mm } & \multirow{4}{*}{ Johansson, 2000} \\
\hline & $7 b$ & $2.39 \times 10^{-3}$ & 1.33 & leaves & & \\
\hline & $7 \mathrm{c}$ & $6 \times 10^{-7}$ & 3.28 & branches & & \\
\hline & $7 \mathrm{~d}$ & $1.19 \times 10^{-3}$ & 2.17 & stem & & \\
\hline
\end{tabular}

